\title{
PENGARUH PAJAK, TUNNELING INCENTIVE DAN MEKANISME BONUS PADA KEPUTUSAN TRANSFER PRICING PERUSAHAAN MANUFAKTUR YANG TERDAFTAR DI BURSA EFEK INDONESIA
}

\author{
Gresia Meriana Purwanto \\ Fakultas Ekonomi, Universitas Wijaya Kusuma Surabaya \\ James Tumewu \\ Fakultas Ekonomi, Universitas Wijaya Kusuma Surabaya \\ e-mail: jamestumewu@gmail.com
}

\begin{abstract}
The aim of this research is to test the influence of tax tunneling incentive and bonus scheme on transfer pricing decision in manufacture companies that listed at Indonesian Stock Exchange. Sample selection was using purposive sampling with final sample 44 from 2012 observation. The result shows that tax and tunneling incentive have an influence on transfer pricing decision, besides than bonus scheme doesn't have an influence on transfer pricing decision. The determination coefficient is $31,8 \%$ that is reflect to variation of tax, tunneling and bonus scheme affect transfer pricing decision. The influence of tax and tunneling is also statistically significant affect transfer pricing. Otherwise the influence of tax and bonus scheme doesn't have statistically significant affect transfer pricing.

The findings give any opportunities to next researchers to investigate the effect of any others variable on transfer pricing decision, such as bonus scheme that based on income. The measurement of transfer pricing using sales to related parties is also relevant proxy and also investigate the effect of any others variable on transfer pricing decision, such as tariffs to the next research.
\end{abstract}

Keywords: bonus scheme, related party transaction, tax, tunneling incentive, transfer pricing

\section{PENDAHULUAN}

\section{Latar Belakang}

Perkembangan yang pesat dari ilmu pengetahuan khususnya perkembangan teknologi informasi berupa makin luasnya pemakaian internet, telah banyak mengubah kehidupan masyarakat dunia. Transaksi internasional yang mencakup barang, jasa dan modal cenderung berorientasi global, dimana batas-batas suatu negara semakin kabur dan dengan sarana internet perdagangan dapat berlangsung tanpa batas. Hal ini membuat arus barang, jasa maupun modal akan masuk dan atau keluar dari suatu negara tanpa hambatan. Kegiatan perdagangan lintas negara membuat pertumbuhan perusahaan multinasional makin pesat. Perusahaan multinasional tersebut, di luar negara tempat kedudukannya mengoperasikan cabang atau anak perusahaan. Pendirian anak perusahaan di berbagai negara merupakan strategi bisnis perusahaan untuk memenangkan persaingan seperti mempertahankan dan mengembangkan pangsa pasar, menguasai sumber-sumber daya yang relatif terbatas. Dalam perusahaan multinasional tersebut, hampir sebagian besar transaksi dan aktivitas ekonomi terjadi antar mereka, seperti transaksi penjualan, pembelian bahan baku, pemberian jasa, penggunaan hak kekayaan intelektual, pemberian pinjaman dan sebagainya.

Keberhasilan operasi-operasi bisnis di luar negeri sangat berkaitan dengan kemampuan untuk beradaptasi dengan faktor-faktor lingkungan yang sangat banyak jumlahnya. Salah satu mekanisme yang digunakan oleh perusahaan multinasional untuk beradaptasi adalah teknik pricing atas sumber daya, jasa dan teknologi yang ditransfer dari satu perusahaan anak ke perusahaan anak yang lain dalam sistem multinasional yang lebih dikenal dengan istilah transfer pricing. Transfer pricing bervariasi dari suatu perusahaan ke perusahaan lain, industri ke industri dan negara ke negara. Transfer pricing dapat mempengaruhi hubunganhubungan sosial, ekonomi, dan politik dalam entitas-entitas bisnis multinasional. Transaksitransaksi yang terjadi antar negara juga mengakibatkan perusahaan-perusahaan multinasional menerima banyak pengaruh dari 
lingkungan yang menciptakan sekaligus mengurangi kesempatan-kesempatan untuk meningkatkan laba perusahaan melalui penyesuaian-penyesuaian harga internal. Faktorfaktor seperti perbedaan tarif pajak, tarif impor, persaingan, laju inflasi, nilai valuta asing, resikoresiko politik, kepentingan-kepentingan mitra usaha patungan, tunneling dan mekanisme bonus membuat keputusan-keputusan transfer pricing semakin rumit. Dan pada akhirnya keputusan tentang transfer pricing umumnya menimbulkan trade-off yang kadang-kadang tidak terduga dan mungkin jarang bisa dijelaskan.

Sebagaimana disebutkan di atas, salah satu faktor yang membuat keputusan transfer pricing semakin rumit adalah perbedaan tarif pajak antar negara. Transfer pricing dapat membuat potensi penerimaan pajak suatu negara berkurang atau hilang. Perusahaan multinasional memiliki kecenderungan untuk menggeser kewajiban perpajakannya dari negara-negara yang memiliki tarif pajak yang tinggi ke negara-negara yang menetapkan tarif pajak rendah. Sehingga dengan demikian terjadi pergeseran dasar pengenaan pajak dari satu negara ke negara lainnya. Hal inilah yang membuat masalah transfer pricing menjadi masalah internasional karena banyak negara yang memiliki kepentingan, terutama bagi negara berkembang seperti Indonesia yang dalam transaksi yang mengandung transfer pricing menjadi negara sumber penghasilan.

Transfer Pricing sendiri sebenarnya sebuah skema yang sering digunakan oleh perusahaan untuk mengefisienkan operasionalnya. Transfer pricing berkaitan erat dengan harga transaksi barang, jasa atau harta tak berwujud antar perusahaan dalam suatu perusahaan multinasional. Transfer pricing dapat dibagi menjadi dua pengertian, yaitu pengertian netral dan pengertian peyoratif. Dalam pengertian peyoratif, transfer pricing bertujuan untuk menurunkan atau bahkan menghindari pengenaan pajak pada laba sebuah perusahaan dengan cara mengalokasikan penghasilan dari suatu perusahaan ke perusahaan lain pada negara yang berbeda, karena setiap negara memiliki peraturan perpajakan yang berbeda-beda. Ada negara yang mengenakan tarif pajak yang tinggi pada laba kena pajak perusahaan, namun juga ada negara yang mengenakan tarif pajak yang rendah pada laba kena pajak perusahaan, atau bahkan ada negara yang tidak mempunyai peraturan anti penghindaran pajak. Pada negara-negara inilah biasanya perusahaan melakukan transfer pricing dengan mudah. Dalam perusahaan, untuk tujuan ekonomi transfer pricing diartikan sebagai penentuan harga barang atau jasa oleh suatu unit departemen dari suatu perusahaan kepada unit departemen lain yang masih dalam satu perusahaan yang sama. Dalam perspektif perpajakan, transfer pricing adalah suatu kebijakan harga dalam transaksi yang dilakukan oleh pihak-pihak yang mempunyai hubungan istimewa (Darussalam, 2013). Dalam perpajakan, terdapat konotasi buruk yang melekat pada transaksi transfer pricing yang sering disebut dengan istilah "abuse of transfer pricing". Kondisi ini terjadi jika transaksi transfer pricing tersebut dimaksudkan untuk tujuan manipulasi perpajakan sehingga adanya shifting profit dari perusahaan yang berada dalam suatu negara yang memiliki tarif pajak tinggi ke negara yang memiliki tarif pajak rendah.

Selain motivasi pajak, keputusan untuk melakukan transfer pricing juga dipengaruhi oleh kepemilikan saham. Struktur kepemilikan di Indonesia terkonsentrasi pada sedikit pemilik, sehingga terjadi konflik keagenan antara pemegang saham mayoritas dengan pemegang saham minoritas. Kepemilikan saham di Indonesia cenderung terkonsentrasi menyebabkan munculnya pemegang saham pengendali dan minoritas (La Porta et al., 2000).

Tunneling adalah transfer aset dan keuntungan keluar dari perusahaan untuk kepentingan pemegang saham mayoritas (Johnson, 2000). Contoh tunneling adalah tidak membagikan dividen, menjual aset atau sekuritas dari perusahaan yang mereka kontrol ke perusahaan lain yang mereka miliki dengan harga di bawah harga pasar, dan memilih anggota keluarganya yang tidak memenuhi kualifikasi untuk menduduki posisi penting di perusahaan. Tunneling juga dapat berupa transfer ke perusahaan induk yang dilakukan melalui transaksi pihak terkait atau pembagian dividen. Transaksi pihak terkait lebih umum digunakan untuk tujuan tersebut daripada pembayaran dividen karena perusahaan yang terdaftar di Bursa harus mendistribusikan dividen kepada perusahaan induk dan pemegang saham minoritas lainnya. Pemegang saham minoritas perusahaan yang terdaftar sering dirugikan ketika harga transfer menguntungkan perusahaan induk atau pemegang saham pengendali.

Keputusan untuk melakukan transfer pricing juga dipengaruhi oleh mekanisme bonus (bonus scheme). Menurut Purwanti (2010), Tantiem / bonus merupakan penghargaan yang diberikan oleh RUPS kepada anggota Direksi setiap tahun apabila 
perusahaan memperoleh laba. Sistem pemberian kompensasi bonus ini akan memberikan pengaruh terhadap manajemen dalam merekayasa laba. Manajer akan cenderung melakukan tindakan yang mengatur laba bersih untuk dapat memaksimalkan bonus yang akan mereka terima. Sistem pemberian kompensasi Bonus, memberikan pengaruh terhadap kinerja manajemen. Dengan menggunakan mekanisme bonus dalam teori keagenan, menjelaskan bahwa kepemilikan manajemen dibawah $5 \%$ terdapat keinginan dari manajer untuk melakukan manajemen laba agar mendapatkan bonus yang besar. Kepemilikan manajemen $25 \%$, karena manajemen mempunyai kepemilikan yang cukup besar dengan hak pengendalian perusahaan, maka asimetris informasi menjadi berkurang. Jika manajemen melakukan pengelolaan laba secara oportunis, maka informasi laba tersebut dapat menyebabkan pengambilan keputusan investasi yang salah bagi investor. Berdasarkan latar belakang tersebut, maka rumusan masalah dalam penelitian ini adalah Apakah Pajak, Tunneling Incentive, dan Mekanisme Bonus berpengaruh terhadap keputusan transfer pricing?

\section{Telaah Pustaka}

Mengembangkan sistem penentuan harga transfer perusahaan multinasional jauh lebih kompleks daripada mengembangkan sistem domestik. Sama seperti perusahaan domestik, sistem penentuan harga transfer perusahaan multinasional seharusnya dapat mendorong manajer untuk membuat keputusan yang mendukung tujuan kantor pusat. Menyediakan kinerja ukuran ekonomi anak perusahaan yang masuk akal kadang merupakan suatu tujuan penentuan harga transfer yang tidak relevan ketika berhadapan dengan perusahaan multinasional. Sistem penentuan harga perusahaan multinasional harus memenuhi tujuan perencanaan strategis, sistem pengendalian manajemen, dan sistem evaluasi kinerja.

Afiliasi adalah bentuk suatu hubungan antara dua atau lebih perseroan yang didasarkan pada kepemilikan saham. Hubungan yang dimaksud adalah hubungan kepemilikan saham voting (voting stock) dan perusahaan-perusahaan yang mempunyai hubungan ini dinamakan perusahaan berafiliasi. Perseroan yang menguasai mayoritas saham voting berhak melakukan kontrol terhadap perseroan lainnya dan dikenal dengan sebutan perusahaan induk, sedangkan perusahaan yang dikontrol atau yang memiliki sebagian kecil saham voting disebut dengan perusahaan anak (Judisseno, 2005:185).

Jensen dan Meckling (1976) mengemukakan teori keagenan yang menjelaskan hubungan antara manajemen perusahaan (agen) dan pemegang saham (prinsipal). Dalam hubungan keagenan (agency relationship) terdapat suatu kontrak satu orang atau lebih (prinsipal) yang memerintahkan orang lain (agen) untuk melakukan suatu jasa atas nama prinsipal dan memberi wewenang kepada agen untuk membuat keputusan yang terbaik bagi prinsipal. Pihak prinsipal juga dapat membatasi divergensi kepentingannya dengan memberikan tingkat insentif yang layak kepada agen dan bersedia mengeluarkan biaya pengawasan (monitoring cost) untuk mencegah hazard dari agen. Namun, sebaliknya teori keagenan juga dapat mengimplikasikan adanya asimetri informasi. Konflik antarkelompok atau agency conflict merupakan konflik yang timbul antara pemilik, dan manajer perusahaan dimana ada kecenderungan manajer lebih mementingkan tujuan individu daripada tujuan perusahaan.

Suatu transfer pricing, sedikitnya melibatkan dua pihak yang melakukan transaksi, yaitu pihak yang melakukan transfer atau transferor dan pihak yang menerima transfer atau transferee, Artikel 9 ayat 1 dari OECD model tax convention menyebutkan bahwa hubungan istimewa dapat diuji melalui test partisipasi manajemen, penguasaan kendali dan modal perusahaan (OECD 2000): "Where: (a) An enterprise of a Contracting State participates directly or indirectly in the management, control or capital of an enterprise of the other Contracting State, or (b) The same persons participate directly or indirectly in the management, control or capital of an enterprise of a Contracting State and an enterprise of the other Contracting State."

Pengertian hubungan istimewa menurut Undang-Undang Pajak Penghasilan No. 36 Tahun 2008 (UU PPh) adalah: "Hubungan istimewa dianggap ada apabila: (a) Wajib Pajak mempunyai penyertaan modal langsung atau tidak langsung paling rendah 25\% (dua puluh lima persen) pada Wajib Pajak lain, atau hubungan antara Wajib Pajak dengan penyertaan paling rendah 25\% (dua puluh lima persen) pada dua Wajib Pajak atau lebih, demikian pula hubungan antara dua Wajib Pajak atau lebih yang disebut terakhir; atau (b) Wajib Pajak menguasai Wajib Pajak lainnya atau dua atau lebih Wajib Pajak berada di bawah penguasaan yang sama baik langsung maupun tidak langsung; atau (c) terdapat hubungan 
keluarga baik sedarah maupun semenda dalam garis keturunan lurus dan atau ke samping satu derajat".

\section{Transfer Pricing}

Transfer pricing adalah harga yang terkandung pada setiap produk atau jasa dari satu divisi yang di transfer ke divisi yang lain dalam perusahaan yang sama atau antar perusahaan yang mempunyai hubungan istimewa. Transaksi transfer pricing dapat terjadi pada divisidivisi dalam satu perusahaan, antar perusahaan lokal, atau perusahaan lokal dengan perusahaan yang ada di luar negeri.

Prinsip dasar harga transfer adalah untuk memaksimalkan laba. Sehingga perusahaan harus secara berkala menjual produk sampai dengan titik dimana tambahan biaya karena adanya tambahan unit yang diproduksi dan dijual, yang disebut marginal cost produksi unit yang diproduksi dan dijual, lebih rendah dibanding penghasilan yang diperoleh dari penjualan unit tersebut (marginal revenue). Dalam hal penentuan harga untuk perusahaan yang terintegrasi, harga harus ditentukan berdasarkan marginal cost produsen.

\section{Pajak}

Menurut UU Perpajakan (UU No. 36 Tahun 2008), yang dimaksud dengan pajak adalah: "Kontribusi wajib kepada negara yang terutang oleh orang pribadi atau badan yang bersifat memaksa berdasarkan undang - undang, dengan tidak mendapatkan imbalan secara langsung dan digunakan untuk keperluan negara bagi sebesar besarnya kemakmuran rakyat" (Primandita, 2011: 4). Kemudian Prof. Dr. Adriani membahas definisi pajak sebagaimana yang dinyatakan sebagai berikut: "Pajak adalah iuran kepada negara yang terutang oleh yang wajib membayarnya menurut peraturan - peraturan, dengan tidak mendapat prestasi kembali, yang langsung dapat ditunjuk, dan yang gunanya adalah untuk membiayai pengeluaran - pengeluaran umum berhubung dengan tugas negara yang menyelenggarakan pemerintahan" (Waluyo, 2011: 2). Jadi dapat disimpulkan bahwa pajak adalah iuran wajib (dapat dipaksakan) yang dibayar berdasarkan undang undang, tidak mendapat balas jasa secara langsung, dan digunakan untuk membiayai pengeluaran pengeluaran Pemerintah.

\section{Tunneling Incentive}

Tunneling merupakan istilah yang awalnya digunakan Negara Republik Ceko untuk menggambarkan kondisi ekspropriasi pemegang saham nonpengendali melalui pengalihan aset dan keuntungan dari suatu perusahaan demi kepentingan pemegang saham pengendali, sepeti proses pengerukan aset melalui terowongan bawah tanah (Guing dan Aria, 2011). Menurut Johnson et al., (2000) tunneling adalah pengalihan keluar aset dan keuntungan dari anak perusahaan untuk kepentingan induk perusahaan yang berdampak pada ekspropriasi pemegang saham nonpengendali.

Tunneling dapat juga dilakukan dengan cara menjual produk perusahaan kepada perusahaan yang memiliki hubungan dengan manajer dengan harga yang lebih rendah dibandingkan mempertahankan posisi/jabatan pekerjaannya meskipun mereka sudah tidak kompeten atau berkualitas lagi dalam menjalankan usahanya atau menjual aset perusahaan kepada perusahaan yang memiliki hubungan dengan manajer (Dwinanto, 2010). Penelitian Johnson et al., (2000) dan Cheung (2006) terbukti bahwa di negara berkembang, pemilik saham mayoritas terlibat dalam praktek ekspropriasi atau tunneling yang dilakukan terhadap pemegang saham minoritas.

\section{Mekanisme Bonus (bonus scheme)}

Menurut Suryatiningsih et al., (2009) skema bonus direksi adalah komponen penghitungan besarnya jumlah bonus yang diberikan oleh pemilik perusahaan atau para pemegang saham melalui RUPS kepada anggota direksi yang dianggap mempunyai kinerja baik setipa tahun serta apabila perusahaan memperoleh laba. Irpan (2010), juga menyatakan bahwa skema bonus direksi dapat diartikan sebagai pemberian imbalan diluar gaji kepada direksi perusahaan atas hasil kerja yang dilakukan dengan melihat prestasi kerja direki itu sendiri. Prestasi kerja yang dilakukan dapat dinilai dan diukur berdasarkan suatu penilaian yang telah ditentukan perusahaan secara objektif.

Mengingat bahwa mekanisme bonus berdasarkan pada besarnya laba, yang merupakan cara paling populer dalam memberikan penghargaan kepada direksi / manajer, maka adalah logis bila direksi yang remunerasinya didasarkan pada tingkat laba akan memanipulasi laba tersebut untuk memaksimalkan peneriman bonus dan remunerasinya. Jadi, dapat disimpulkan bahwa mekanisme bonus merupakan salah satu strategi atau motif perhitungan dalam akuntansi yang tujuannya adalah untuk memberikan penghargaan kepada direksi atau manajemen 
dengan melihat laba perusahaan secara keseluruhan. Karena sebagai akibat dari adanya praktik transfer pricing maka tidak menutup kemungkinan akan terjaadi kerugian pada salah satu divisi atau subunit. Merujuk kepada pendapat Horngren (2008: 428), yang menyebutkan bahwa kompensasi bonus dilihat berdasarkan tim bervariasi di berbagai divisi dalam satu organisasi. Sebagai tim perusahaan maka harus bersedia untuk saling membantu. Jadi bonus direksi tidak didasarkan pada laba subunit namun berdasarkan pada kebaikan dan laba perusahaan secara keseluruhan.

\section{Pajak dan Transfer Pricing}

Perusahaan seharusnya mengunakan prinsip harga wajar untuk mengurangi kewajiban pajak, tetapi perusahaan lebih banyak menggunakan transfer pricing. Klassen et al., (1993) menemukan bahwa terjadi pergeseran pendapatan oleh perusahaan multinasional sebagai respon terhadap tingkat perubahan pajak di Kanada, Eropa, dan Amerika Serikat. Perusahaan multinasional menggeser pendapatan dari Kanada ke AS, sedangkan penurunan tarif pajak di Eropa menggeser pendapatan dari AS ke Eropa.

Gusnardi (2009), menyebutkan bahwa perusahaan multinasional melakukan transfer pricing adalah untuk meminimalkan kewajiban pajak gobal perusahaan mereka. Kemudian menurut Yani (2001), motivasi pajak dalam transfer pricing pada perusahaan multinasional tersebut dilaksanakan dengan cara sedapat mungkin memindahkan penghasilan ke negara dengan beban pajak terendah atau minimal dimana negara tersebut memiliki grup perusahaan atau divisi perusahaan yang beroperasi.

Yuniasih et al., (2012), mengungkapkan bahwa pajak berpengaruh positif pada keputusan perusahaan untuk melakukan transfer pricing. Beban pajak yang semakin besar memicu perusahaan untuk melakukan transfer pricing dengan harapan dapat menekan beban tersebut. Karena dalam praktik bisnis, umumnya pengusaha mengidentikkan pembayaran pajak sebagai beban sehingga akan senantiasa berusaha untuk meminimalkan beban tersebut guna mengoptimalkan laba.

\section{Hipotesis}

Berdasarkan rumusan di atas maka hipotesis dalam penelitian ini adalah sebagai berikut.

$\mathrm{H}_{1}$ : pajak berpengaruh pada keputusan transfer pricing

\section{Tunneling Incentive dan Transfer Pricing}

Struktur Kepemilikan mencerminkan jenis konflik keagenan yang terjadi. Ada 2 macam struktur kepemilikan, yaitu struktur kemilikan tersebar dan struktur kepemilikan terkonsentrasi (Mutamimah, 2008). Struktur kepemilikan tersebar mempunyai ciri bahwa manajemen perusahaan dikontrol oleh manajer. Manajer lebih mengutamakan kepentingannya dibanding kepentingan pemegang saham. Dalam struktur kepemilikan ini, pemegang saham secara umum tidak bersedia melakukan monitoring, karena mereka harus menanggung seluruh biaya monitoring dan hanya menikmati keuntungan sesuai dengan proporsi kepemilikan saham mereka. Jika semua pemegang saham berperilaku sama, maka tidak akan terjadi pengawasan terhadap manajemen (Zhuang et al., 2000). Dengan demikian, konflik keagenan yang terjadi pada struktur kepemilikan tersebar adalah konflik keagenan antara manajer dengan pemegang saham (Jensen dan Meckling, 1976).

Tunneling merupakan perilaku manajemen atau pemegang saham mayoritas yang mentransfer aset dan profit perusahaan untuk kepentingan mereka sendiri, namun biaya dibebankan kepada pemegang saham minoritas (Zhang, 2004 dalam Mutamimah, 2008). Sansing (1999) menunjukkan bahwa pemegang saham mayoritas dapat mentransfer kekayaan untuk dirinya sendiri dengan mengorbankan hak para pemilik minoritas, dan terjadi penurunan pengalihan kekayaan ketika persentase kepemilikan pemegang saham mayoritas menurun. Mutamimah (2008) menemukan bahwa terjadi tunneling oleh pemilik mayoritas terhadap pemilik minoritas melalui strategi merger dan akuisisi. Lo et al., (2010) menemukan bahwa konsentrasi kepemilikan oleh pemerintah berpengaruh pada keputusan transfer pricing. Aharony et al., (2010) menemukan bahwa tunneling incentive setelah initial public offering (IPO) berhubungan dengan penjualan hubungan istimewa sebelum IPO. Oleh karena itu, penelitian ini menduga bahwa:

$\mathrm{H}_{2}$ : Tunneling incentive berpengaruh pada keputusan transfer pricing.

\section{Mekanisme Bonus dan Transfer Pricing}

Dalam menjalankan tugasnya, para direksi cenderung ingin menunjukkan kinerja yang baik kepada pemilik perusahaan. Karena apabila pemilik perusahaan atau para pemegang saham sudah menilai kinerja para direksi dengan penilaian yang baik maka pemilik perusahaan akan memberikan penghargaan kepada direksi yang 
telah mengelola perusahaannya dengan baik. Penghargaan itu dapat berupa bonus yang diberikan kepada direksi perusahaan. Dalam memberikan bonus kepada direksi, pemilik perusahaan akan melihat kinerja para direksi dalam mengelola perusahaanya. Pemilik perusahaan dalam menilai kinerja para direksi biasanya melihat laba perusahaan secara keseluruhan yang dihasilkan.

Merujuk pada penelitian Lo et al., (2010) dari Amerika, yang menemukan bahwa terdapat kecenderungan manajemen memanfaatkan transaksi transfer pricing untuk memaksimalkan bonus yang mereka terima jika bonus tersebut didasarkan pada laba. Jadi dapat disimpulkan bahwa manajer akan cenderung melakukan tindakan yang mengatur laba bersih dengan cara melakukan praktik transfer pricing agar dapat memaksimalkan bonus yang mereka terima. Oleh karena itu penelitian ini menduga bahwa:

$\mathrm{H}_{3}$ : mekanisme bonus berpengaruh terhadap keputusan transfer pricing

\section{METODE PENELITIAN \\ Populasi dan sampel}

Penelitian ini dilakukan pada perusahaan manufaktur yang terdaftar di Bursa Efek Indonesia tahun 2012. Sampel dalam penelitian ini menggunakan metode purposive sampling dengan kriteria sebagai berikut.

1 Penelitian ini menggunakan perusahaan manufaktur yang listing di Bursa Efek Indonesia.

2 Data laporan keuangan maupun data ICMD perusahaan sampel tersedia untuk tahun pelaporan 2012.

3 Perusahaan Sampel termasuk dalam kategori Perusahaan Multinasional, yaitu perusahaan yang memiliki induk maupun anak cabang di Negara lain.

4 Perusahaan sampel tidak mengalami kerugian selama periode pengamatan. Hal ini karena perusahaan yang mengalami kerugian tidak memiliki kewajiban perpajakan di tingkat perusahaan sehingga motivasi pajak menjadi tidak relevan. Oleh karena itu perusahaan yang mengalami kerugian dikeluarkan dari sampel.

5 Perusahaan sampel dikendalikan oleh perusahaan asing dengan persentase kepemilikan $20 \%$ atau lebih. Hal ini sesuai dengan PSAK No. 15 yang menyatakan bahwa pemegang saham pengendali adalah pihak yang memiliki saham atau efek yang bersifat ekuitas sebesar $20 \%$ atau lebih.

Tabel 1

Pemilihan Sampel

\begin{tabular}{lc}
\hline \multicolumn{1}{c}{ Kriteria } & Jumlah \\
\hline $\begin{array}{l}\text { Perusahaan sektor manufaktur yang } \\
\text { terdaftar di BEI selama periode 2012 }\end{array}$ & 151 \\
\hline $\begin{array}{l}\text { Perusahaan sampel yang tidak } \\
\text { memiliki persentase kepemilikan asing } \\
\text { minimal 20\% }\end{array}$ & -68 \\
\hline $\begin{array}{l}\text { Perusahaan sampel yang tidak bersifat } \\
\text { Multinational Company (MNC) }\end{array}$ & -32 \\
\hline $\begin{array}{l}\text { Perusahaan sampel yang mengalami } \\
\text { kerugian selama 2012 }\end{array}$ & -7 \\
\hline Jumlah Sampel Akhir & $\mathbf{4 4}$ \\
\hline
\end{tabular}

Sumber: BEI, data diolah 2014

\section{Definisi Operasional Variabel \\ Pajak}

Pajak merupakan Kontribusi wajib kepada negara yang terutang oleh orang pribadi atau badan yang bersifat memaksa berdasarkan undang undang, dengan tidak mendapatkan imbalan secara langsung dan digunakan untuk keperluan negara bagi sebesar-besarnya kemakmuran rakyat. Pajak dalam penelitian ini diproksikan dengan effective tax rate yang merupakan perbandingan tax expense dikurangi differed tax expense (Lebih dikenal dengan pajak kini) dibagi dengan laba kena pajak (Yuniasih et al., 2012).

\section{Tunneling Incentive}

Tunneling incentive diproksikan dengan persentase kepemilikan saham di atas $20 \%$ sebagai pemegang saham pengendali oleh perusahaan asing. Kriteria struktur kepemilikan terkonsentrasi didasarkan pada UU Pasar Modal No. IX.H.1, yang menjelaskan pemegang saham pengendali adalah pihak yang memiliki saham atau efek yang bersifat ekuitas sebesar $20 \%$ atau lebih (Mutamimah, 2008). PSAK No. 15 juga menyatakan bahwa tentang pengaruh signifikan yang dimiliki oleh pemegang saham dengan persentase $20 \%$ atau lebih.

\section{Mekanisme Bonus (Bonus Scheme)}

Bonus scheme (mekanisme bonus) merupakan salah satu motif pemilihan suatu metoda akuntansi tidak terlepas dari positif accounting theory. Mekanisme bonus merupakan komponen penghitungan besarnya jumlah bonus yang diberikan oleh pemilik perusahaan atau para 
pemegang saham melalui RUPS kepada anggota direksi setiap tahun apabila memperoleh laba (Suryatiningsih, 2009). Untuk variabel ini akan diukur dengan komponen perhitungan indeks trend laba bersih. Menurut Irpan (2010), Indeks trend laba bersih (ITRENDLB) di hitung berdasarkan persentase pencapaian laba bersih tahun $t$ terhadap laba bersih tahun $\mathrm{t}-1$.

\section{Transfer Pricing}

Transfer Pricing adalah harga yang terkandung pada setiap produk atau jasa dari satu divisi yang di transfer ke divisi yang lain dalam perusahaan yang sama atau antar perusahaan yang mempunyai hubungan istimewa. Transaksi transfer pricing dapat terjadi pada divisi-divisi dalam satu perusahaan, antar perusahaan lokal, atau perusahaan lokal dengan perusahaan yang ada di luar negeri.

Transfer pricing dihitung dengan pendekatan dikotomi yaitu dengan melihat keberadaan penjualan kepada pihak yang mempunyai hubungan istimewa. Perusahaan yang melakukan penjualan kepada pihak yang mempunyai hubungan istimewa diberi nilai 1 dan yang tidak diberi nilai 0 .

Analisis data dilakukan dengan menggunakan teknik analisis regresi logistik (Binary Logistic Regresion). Teknik ini digunakan karena variabel terikat dalam penelitian ini yaitu transfer pricing bersifat dikotomus atau merupakan variabel dummy. Teknik analisis ini tidak memerlukan lagi uji normalitas dan uji asumsi klasik pada variabel bebasnya (Ghozali, 2006). Model regresi logistik ditunjukkan dalam persamaan sebagai berikut.

$$
\begin{array}{ll}
\mathrm{Y}=\beta_{0}+\beta_{1} \mathrm{X}_{1}+\beta_{2} \mathrm{X}_{2}+\beta_{3} \mathrm{X}_{3} \mathrm{e} \\
\text { Keterangan: } \\
\mathrm{Y} \quad=\text { Transfer Pricing } \\
\mathrm{X}_{1} \quad \text { = Pajak } \\
\mathrm{X}_{2} \quad=\text { Tunneling Incentive } \\
\mathrm{X}_{3} \quad=\text { Mekanisme Bonus (Bonus Scheme) } \\
\beta_{0} \quad=\text { Nilai Y bila } \mathrm{X}=0 \\
\mathrm{~B}_{\mathrm{N}} & =\text { Koefisien Regresi } \\
\mathrm{e} & =\text { adalah } \text { error } \text { atau sisa (residual) }
\end{array}
$$

\section{PEMBAHASAN}

Sampel yang digunakan dalam penelitian ini adalah sebanyak 44 pengamatan perusahaan manufaktur selama periode 2012. Statistik deskriptif menunjukkan bahwa transaksi hubungan istimewa terjadi pada 37 pengamatan, yang berarti sebagian besar perusahaan melakukan transaksi transfer pricing. Dilihat dari sisi kepemilikan, ratarata persentase kepemilikan perusahaan adalah sebesar 56,72\%. Ini menunjukkan bahwa kepemilikan saham perusahaan sampel cenderung terkonsentrasi pada sebagian kecil pihak.

Pengujian hipotesis dilakukan dengan menggunakan regresi logistik. Kelayakan model regresi dinilai dengan menggunakan Hosmer and Lemeshow's Goodness of Fit Test. Pengujian menunjukkan nilai Chi-square sebesar 7,009 dengan signifikansi sebesar 0,536. Nilai -2LL awal adalah sebesar 38,559. Setelah dimasukkan ketiga variabel independen, maka nilai -2LL akhir mengalami penurunan menjadi sebesar 29,529. Penurunan likelihood (-2LL) ini menunjukkan model regresi yang lebih baik atau dengan kata lain model yang dihipotesiskan fit dengan data.

Besarnya nilai koefisien determinasi pada model regresi logistik ditunjukkan oleh nilai Nagelkerke $R$ Square. Nilai Nagelkerke $R$ Square adalah sebesar 0,318 yang berarti variabilitas variabel dependen yang dapat dijelaskan oleh variabel independen adalah sebesar 31,8\% sedangkan sisanya sebesar $68,2 \%$ dijelaskan oleh variabel-variabel lain di luar model penelitian.

Hasil pengujian hipotesis menunjukkan bahwa pajak dan tunneling incentive berpengaruh positif pada keputusan transfer pricing. Ini dapat dilihat dari tingkat signifikansi masing-masing sebesar 0,046 dan 0,049 yang lebih kecil dari 0,05. Hasil ini konsisten dengan hipotesis yang diajukan. Sementara Mekanisme bonus tidak berpengaruh positif pada keputusan transfer pricing. Ini dapat dilihat dari tingkat signifikansi sebesar 0,866 yang lebih besar dari 0,05. Hasil ini tidak konsisten dengan hipotesis yang diajukan.

Besarnya keputusan untuk melakukan praktik transfer pricing akan mengakibatkan pembayaran pajak menjadi lebih rendah secara global pada umumnya. Hal ini disebabkan karena perusahaan multinasional yang memperoleh keuntungan akan melakukan pergeseran pendapatan dari negara negara dengan tarif pajak tinggi ke negara - negara dengan tarif pajak yang rendah. Sehingga semakin tinggi tarif pajak suatu negara maka akan semakin besar kemungkinan perusahaan melakukan praktik transfer pricing.

Hasil ini sesuai dengan penelitian Ni Wayan Yuniasih, Ni Ketut Rasmini, dan Made Gede Wirakusuma (2011) yang menyatakan bahwa pajak berpengaruh signifikan terhadap keputusan transfer pricing. Mitigasi pajak juga ada peluang untuk penjualan domestik antara perusahaan terkait karena perbedaan tingkat pajak. Beban pajak yang semakin besar memicu perusahaan untuk melakukan transfer pricing dengan harapan dapat 
menekan beban tersebut, Karena dalam praktik bisnis, umumnya pengusaha mengidentikkan pembayaran pajak sebagai beban sehingga akan senantiasa berusaha untuk meminimalkan beban tersebut guna mengoptimalkan laba.

Negara-negara berkembang seperti Indonesia dan negara Asia lainnya cenderung memiliki struktur kepemilikan terkonsentrasi yang secara umum didominasi oleh keluarga pendiri serta lemahnya perlindungan terhadap pemegang saham minoritas menimbulkan konflik keagenan antara pemegang saham mayoritas dengan pemegang saham minoritas (Liu and $\mathrm{Lu}, 2007$ ). Kondisi ini sesuai dengan pernyataan Prowsen (1998), bahwa konflik keagenan yang utama di Indonesia adalah konflik keagenan antara pemegang saham mayoritas dengan pemegang saham minoritas. Tunneling merupakan perilaku manajemen atau pemegang saham mayoritas yang mentransfer aset dan profit perusahaan untuk kepentingan mereka sendiri, namun biaya dibebankan kepada pemegang pemegang saham minoritas (Zhang, 2004 dalam Mutamimah, 2008).

Hasil ini sesuai dengan penelitian Ni Wayan Yuniasih, Ni Ketut Rasmini, dan Made Gede Wirakusuma (2011) yang menyatakan bahwa tunneling incentive berpengaruh signifikan terhadap keputusan transfer pricing. Transaksi pihak terkait lebih umum digunakan untuk tujuan transfer kekayaan daripada pembayaran dividen karena perusahaan yang terdaftar di Bursa harus mendistribusikan dividen kepada perusahaan induk dan pemegang saham minoritas lainnya.

Dalam memberikan bonus kepada direksi, pemilik perusahaan tentu akan melihat kinerja para direksi dalam mengelola perusahaanya. Dalam hal ini, pemilik perusahaan akan melihat laba perusahaan yang dihasilkan secara keseluruhan sebagai penilaian untuk kinerja para direksinya. Untuk itu, para direksi tentu akan berusaha semaksimal mungkin agar laba perusahaan secara keseluruhan mengalami peningkatan. Merujuk kepada pendapat Horngren (2008:428), yang menyebutkan bahwa kompensasi bonus dilihat berdasarkan tim bervariasi di berbagai divisi dalam satu organisasi. Sebagai tim perusahaan maka harus bersedia untuk saling membantu. Jadi bonus direksi tidak didasarkan pada laba subunit namun berdasarkan pada kebaikan dan laba perusahaan secara keseluruhan.

Variabel kompensasi tidak selalu menjadikan motivator bagi dewan direksi untuk melakukan keputusan transfer pricing. Besarnya kompensasi bukan merupakan motivasi utama bagi dewan direksi untuk melakukan keputusan transfer pricing. Hal ini dikarenakan sebelum melakukan keputusan transfer pricing dewan direksi harus melakukan analisa terhadap resiko yang mungkin akan dihadapinya jika melakukan keputusan transfer pricing. Tidak berpengaruhnya kompensasi terhadap keputusan transfer pricing dikarenakan peluang dewan direksi untuk melakukan keputusan transfer pricing juga dimotivasi oleh pengendalian internal perusahaan.

\section{PENUTUP \\ Kesimpulan}

Penelitian ini bertujuan untuk menganalisis pengaruh Pajak, Tunneling Incentive, dan Mekanisme Bonus terhadap keputusan Transfer Pricing. Berdasarkan analisa data dengan sampel 44 pengamatan perusahaan manufaktur yang terdaftar di Bursa Efek Indonesia, pengujian hipotesis serta pembahasannya maka dapat ditarik kesimpulan bahwa, Variabel pajak berpengaruh signifikan terhadap keputusan transfer pricing satu periode (2012). Besarnya keputusan untuk melakukan praktik transfer pricing akan mengakibatkan pembayaran pajak menjadi lebih rendah secara global pada umumnya. Hal ini disebabkan karena perusahaan multinasional yang memperoleh keuntungan akan melakukan pergeseran pendapatan dari negara-negara dengan tarif pajak tinggi ke negara-negara dengan tarif pajak yang rendah. Sehingga semakin tinggi tarif pajak suatu negara maka akan semakin besar kemungkinan perusahaan melakukan praktik transfer pricing.

Hasil penelitian menunjukkan bahwa tunneling incentive berpengaruh signifikan terhadap keputusan transfer pricing selama satu periode (2012). Transaksi pihak terkait lebih umum digunakan untuk tujuan transfer kekayaan daripada pembayaran dividen karena perusahaan yang terdaftar harus mendistribusikan dividen kepada perusahaan induk dan pemegang saham minoritas lainnya. Kondisi yang unik dimana kepemilikan saham pada perusahaan publik di Indonesia cenderung terkonsentrasi sehingga ada kecenderungan pemegang saham mayoritas untuk melakukan tunneling.

Variabel kompensasi tidak selalu menjadikan motivator bagi dewan direksi untuk melakukan keputusan transfer pricing. Besarnya kompensasi bukan merupakan motivasi utama bagi dewan direksi untuk melakukan keputusan transfer pricing. Hal ini dikarenakan sebelum melakukan keputusan transfer pricing dewan direksi harus 
melakukan analisa terhadap resiko yang mungkin akan dihadapinya jika melakukan keputusan transfer pricing.

\section{Keterbatasan Penelitian}

Penelitian ini memiliki beberapa keterbatasan, yang apabila diatasi pada penelitian selanjutnya akan dapat memperbaiki hasil penelitian. Beberapa saran yang dapat dikemukakan dalam kaitannya dengan keterbatasan penelitian ini diantaranya, Penelitian-penelitian selanjutnya diharapkan dapat menggunakan variabel lain yang mungkin berpengaruh pada keputusan perusahaan untuk melakukan transfer pricing. Salah satunya adalah tarif, dimana tarif yang lebih tinggi akan meningkatkan gap antara harga wajar dengan harga hubungan istimewa. Perusahaan menggunakan harga yang lebih rendah ketika melakukan ekspor kepada perusahaan dengan tarif impor yang tinggiPada penelitian selanjutnya diharapkan dapat menggunakan proksi transfer pricing yang lain jika tersedia data tentang penjualan kepada pihak yang memiliki hubungan istimewa dengan lebih rinci.

\section{DAFTAR PUSTAKA}

Agoes, Sukrisno dan Estralita Trisnawati. 2013. Akuntansi Perpajakan, Edisi 3. Jakarta, Salemba Empat.

Aharony, J., J. Wang, and H. Yuan. 2010. Tunneling as An Incentive for Earnings Management During The IPO Process in China. Journal of Accounting and Public Policy. Vol. 29, 1-26.

Arifin, Z. 2003. "Masalah Keagenan dan Mekanisme Kontrol pada Perusahaan dengan Struktur Kepemilikan Terkonsentrasi yang Dikontrol Keluarga: Bukti dari Perusahaan Publik di Indonesia." Disertasi Tidak Dipublikasikan, Program Studi Ilmu Manajemen, Universitas Indonesia.

Blocher, Edward J., Kung H. Chen dan Thomas W.Lin, 1999. Manajemen Biaya Buku 1, Terjemahan Susty Ambarrani, Salemba Empat, Jakarta.

Choi, Frederick D.S, Mueller Gerhard G, 2006. Akuntansi Internasional, buku 1, edisi 5, Penerbit PT. Salemba Empat, Jakarta.

Claesens, S, D. Simeon, H.P.L Larry. 2000. The Separation of Ownership and Control in East Asia. Journal of Financial Economics. 81-112.
Claesens, S, D. Simeon, H.P.L Larry. 2002. Expropriation of Minority Shareholder in East Asia. The Journal of Financial.

Colgan, P. Mc. 2001. "Agency Theory and Corporate Governance: A Review of the Literature From a UK Perspective". Working paper.

Darussalam, Septriadi, D., dan Kristiaji, B. B. 2013. Transfer Pricing Ide, Strategi, dan Panduan Praktis dalam Perspektif Pajak Internasional. Jakarta: PT Dimensi Internasional Tax.

Dyanty, V., Sidharta, U., Hilda, R., dan Sylvia, V. 2012. Pengaruh Kepemilikan Pengendali Akhir Terhadap Transaksi Pihak Berelasi.Jurnal Simposium Nasional Akuntansi XV. Banjarmasin, 20-22 September 2012.

Fitriandi, Primandita. 2011. Kompilasi UndangUndang Perpajakan Terlengkap. Jakarta: Salemba Empat.

Gao, L., Gerhard K, G., 2008. Corporate Governance and Tunneling: Emperical evidence from China, Pacific Basin Finance Journal (16), 591-605

Ghozali, Imam. 2006. Aplikasi Analisis Multivariate dengan Program SPSS. Semarang: BP Undip.

Gordon, E.A.dan E.Henry and D.Palia (2004a). "Related Party Transaction and Corporate Governance."Advances in Financial Economics, Vol 9:1-27.

Guing, A dan Aria, F. 2011. Manajemen laba dan Tunneling Melalui Transaksi Pihak Istimewa Di Sekitar Penawaran Saham Perdana. Jurnal Simposium Nasional Akuntansi XIV. Banda Aceh, 21-22 Juli 2011 Gunadi. 1994. Transfer Pricing. Suatu Tinjauan Akuntansi Manajemen dan Pajak. Jakarta: Bina Rena Pariwara.

Gusnardi. 2009. Penetapan Harga Transfer Dalam Kajian Perpajakan. Pekbis Jurnal. Vol. 1.No. 1. Universitas Riau. Pekanbaru.

Horngren, T, Charles, Srikant M, Datar, dan George Foster. 2008. Akuntansi Biaya: Dengan Penekanan Manajerial.. Jakarta: Erlangga.

Hartati, Winda, Desmiyawati dan Nur Aslina. 2014. Analisis Pengaruh Pajak Dan Mekanisme Bonus Terhadap Keputusan Transfer Pricing Studi Empiris Pada Seluruh Perusahaan Yang Listing Di Bursa Efek Indonesia. Jurnal Universitas Riau. 
Hill, Charles W.L. 2003. International Business: Competing in the Global Marketplace. Fourth Edition. McGraw-Hill, New York.

Indriantoro, dan Supomo, 2002.Metodologi Penelitian Bisnis untuk Akuntansi dan Manajemen, Edisi Pertama, BPFEYogyakarta, Yogyakarta

IAI. 2009. Standar Akuntansi Keuangan. Jakarta: Salemba Empat.

Irpan. 2010. Analisis Pengaruh Skema Bonus Direksi, jenis Usaha, ProfitabilitasPerusahaan, dan Ukuran Perusahaan Terhadap Earning Management: Studi Empiris Pada Perusahaan Manufaktur dan Keuangan yang Listing Di BEI Paada Tahun 20082010. Skripsi. Fakultas Ekonomika dan Bisnis. UIN Syarif Hidayatullah. Jakarta.

Jacob, J. 1996. Taxes and Transfer Pricing: Income Shifting and The Volume of Intrafirm Transfer. Journal of Accounting Research 34. 301-312

Jensen, M. and W.H. Meckling. 1976. Theory of the Firm: Magerial Behavior, Agency Cost and Ownership Structure. Journal of Financial Economics 3. 305-360.

Johnson Simon, Rafael La Porta, Florencio Lopez de Silanes and Andrei Shleifer, 2000,"Tunneling", American Economic Review Review Papers and Proceeding 90,22-27.

Judisseno, K, Rimsky. 2005. Pajak dan Strategi Bisnis: Suatu Tinjauan tentang Kepastian Hukum dan Penerapan Akuntansi di Indonesia. Jakarta: PT Gramedia Pustaka Utama.

Klassen, Kenneth, Petro Lisowsky and Devan Mescall. 2013. Transfer Pricing: Strategies, Practices, and Tax Minimazation, Journal of Tax Excecutive Institute (TEI). The University of Illionis.

La Porta, R., F. Lopez-de-Silanes, A. Shleifer, and R.W. Vishny. 1999. Agency problems and Dividend Policies around the Word. The Journal of Financial. 1-33.

Lo, W. Y. A., Raymond. M.K. W., and Micheal F. 2010. Tax, Financial Reporting, and Tunneling Incentives for Income Shifting: An Empirical Analysis of the Transfer Pricing Behavior of Chinese-Listed Companies. Journal of the American Taxation Association. Vol. 32, No. 2: 1-26.
Mueller, G.G., H. Gernon, dan G. Meek. 1987. Accounting: An International Perspective. Homewood III: Richard D. Irwin.

Murni dan Djamilah. 2009. Metodelogi Penelitian, Surabaya

Muslich Anshori dan Sri Iswati, (2009), "Metode Penelitian Kuantitatif", AUP, Surabaya

Mutaminah. 2008. Tunneling atau Value Added dalam Strategi Merger dan Akuisisi di Indonesia. Manajemen \& Bisnis. Vol. 7, No. 1. OECD. 2000.

Purwanti, Lilik. 2010. Kecakapan Managerial, Skema Bonus, Managemen Laba, dan Kinerja Perusahaan. Jurnal Aplikasi Manajemen Vol. 8. No. 2.

Sansing, R. C. 1999. Economic Foundations of Valuation Discounts. The Journal of the American Taxation Association 21: 28-38.

Santoso, Iman. 2004. Advance Pricing Agreement dan Problematika Transfer Pricing Dari perspektif Perpajakan Indonesia. Jurnal Akuntansi dan Keuangan Vol. 6. No. 2.

Sartono, R. Agus. 2003. Manajemen Keuangan Internasional. Edisi Pertama. BPFE, Yogyakarta.

Sheifer, A, and R.W. Vishny, 1997, A Survey of Corporate Governance, Journal of Financial Economics, 737-783.

Siregar, V. S. N. P. 2006. "Pengaruh Stuktur Kepemilikan, Ukuran Perusahaan, dan Praktek Corporate Governance terhadap Pengelolaan Laba". Jurnal riset Akuntansi IndonesiaSuandy, Erly. 2011. Hukum Pajak. Jakarta: Salemba Empat. 